\title{
A parental school choice misery: Middle class parents' dilemma in choosing a primary school in Berlin's multi-ethnic neighborhoods
}

Tanja Mayer, Viktor Geist, Vera S. Pohl, Judith Schwarz, Thomas Koinzer

Abstract: To follow up on research conducted in several countries, in this paper, we look at the dilemmas middle-class parents face of being "good parents" by choosing the "best" school with a milieu-related environment for their child versus being "good citizens" by choosing a "local" public school with a large proportion of students from a working-class or migrant background. Analyzing semi-structured interviews with parents, the paper explores whether and how parents in Germany's capital city of Berlin refer to this dilemma concerning primary school choice and how they resolve it and justify their decision. The parents interviewed applied strategies in deciding to be "good parents" or "good citizens" or at least to make it easier to solve the dilemma. All the strategies presented in other studies can be found in our sample as well. In addition, we identified two more parental strategies: the strategy of downward comparison and the strategy of choosing a private school. It is notable that the perceived proportion of children with a migrant background in the neighborhood played a major role in relation to the dilemma and the strategies chosen.

Keywords: school choice, segregation, private school, neighborhood, spatial inequalities

In recent years, middle-class parents and the choices they make about their children's educations, including which schools to send them to, have been the focus of international research (Förste, 2013). In this paper, we 
analyzed middle-class parents' school choices: choosing a primary school in urban and socially and ethnically mixed neighborhoods. While studies have already been performed in England, the US, and France (Raveaud \& van Zanten, 2007; Crozier et al., 2008; James et al., 2010; Kimelberg \& Billingham, 2012; Cucchiara, 2013), little research has been conducted in Germany. Following up on the research from other countries, in this paper we take a special look at the dilemma parents face between being "good parents" by choosing the "best school" for their child versus being "good citizens" by choosing a "local school" with a large proportion of students from a working-class or migrant background. Analyzing semi-structured interviews with parents, the paper focuses on whether and how parents in the German capital Berlin refer to this dilemma concerning primary school choice and how they resolve and justify it.

\section{Theoretical Framework and State of the Art}

Choosing the "right" school is an important topic among urban, educated, middle-class parents who perceive school choice as a way of maintaining their economic, cultural, and symbolic resources (Bourdieu, 1983). As different studies have shown, educational and school choices are important issues for middle-class parents, and such decisions are linked to educational inequality and segregation (e.g. Butler \& Robson, 2003; Förste, 2013). Studies have pointed out that middle-class parents choose schools in a more distinctive way, involving strategic choices on residential neighborhood, than do, for example, working-class parents. This has led to a "geography of school choice" and an increasing level of segregation (Förste, 2013).

The dilemmas involved in school choice

Frank and Weck (2018) showed that German middle-class parents who live in mixed neighborhoods before their child starts school can be divided into two types: For the first type of parent, the impending enrollment is the trigger for moving to a neighborhood that is more in keeping with their own middle-class status and milieu. The second type of parent continues to live in the mixed neighborhood but is simultaneously confronted with the problem of school choice because the schools in the immediate vicinity are perceived as unsuitable. These two types can also be described as parents who are facing the decision of being "good parents" or "good citizens." Frank and Weck showed that "good parents" try to create a good environment for the child by moving to a "better" neighborhood. If, by contrast, parents decide to stay in the mixed inner-city neighborhood, they often justify this by making 
social commitments that allow them to feel they are being "good citizens" (Frank \& Weck, 2018). Ball and Vincent (2007) came to a similar conclusion. They showed that in London, two groups of middle-class parents were found: parents who avoided and parents who preferred ethnic diversity. The two groups differ in having "not necessarily distinct, localized middle-class habituses, which are rooted in different combinations of capital and forms of social relationships" (p.76, Ball \& Vincent, 2007).

In this paper, we focus on the group of middle-class parents who decided to remain in mixed, fairly marginalized, multi-ethnic urban neighborhoods and who were thus increasingly affected by the choice of where to send their children to school or rather whether they should send their children to a "good" public or private school. We should note that parental evaluations of whether a school is good or bad are less dependent on the hard, measurable quality criteria commonly used in, for example, student assessments. Instead, for parents, the social mix of students is an important element in defining what is meant by a good school (Frank \& Weck, 2018). Even though some research indicates that socially and ethnically mixed schools could be more advantageous for children from all social backgrounds (Nast \& Blokland, 2014), a large proportion of children with a different first language or from families with a low social status are viewed critically by parents choosing a school.

Middle-class parents who are open-minded about ethnic diversity living in mixed neighborhoods were the focus of a study by Raveaud and van Zanten (2007) comparing Paris and London. They pointed out that parents who have a high level of education holding a "caring perspective," and who are liberal-minded (ibid, p. 107), often find themselves in a dilemma. For those living in a heterogeneous neighborhood with (small) gentrified areas, there are two options regarding school choice:

1) Choosing the "best" school with a (relatively) small proportion of socially disadvantaged children or students with a migrant background. Here the parental focus is on good educational achievement and the best school environment for the child. ("good parents")

2) Choosing a local school with a large proportion of socially disadvantaged children or students with a migrant background. Here the parental focus is on a society-oriented view linked to inclusion, integration, and educational equality. ("good citizens") 
Similar to Frank and Weck's (2018) description of the dilemma over choice of residence, this decision arises again when it comes to school choice for parents living (or remaining) in mixed neighborhoods. Along with Raveaud and van Zanten (2007), other studies have identified the school-choice dilemma described for middle-class parents in mixed neighborhoods: Crozier et al. (2008) showed a similar dilemma in England. The sample consisted only of parents who had chosen a local comprehensive school for their child instead of an affordable private school. The dilemma mentioned in the interviews was described as "acting in self-interest" versus "acting against self-interest" (ibid, p. 261). They showed that acting in one's self-interest was related to making the best decision concerning the child, while considering a good academic career and social prestige. By contrast, acting against one's self-interest was associated with the parents' moral and political beliefs such as their beliefs about equality or social justice ${ }^{1}$. Another study on primary school choice in the US in the cities of Boston, Kimelberg, and Billingham (2012) showed that some parents expressed a desire for diversity on the one hand but were also afraid that their middle-class child would be in the minority at a mixed school and that this would have negative consequences. Cucchiara (2013) interviewed American middle-class parents who chose a local, socioeconomically mixed school. These parents wondered about various risks and anxieties, both with regard to the "overly anxious parenting culture" (ibid, p. 76) and the perceived dangers associated with choosing a socially and ethnically mixed school. Although the sample and the arguments differed slightly from those in Raveaud and van Zanten's (2007) study, the dilemma between being a good parent versus being a good citizen could be seen here as well.

\section{Strategies}

In sum, most parents try to make the best decision and to be both good parents and good citizens. Ultimately, a decision has to be made and values have to be considered because a good compromise between the two divergent options is usually not possible (Frank \& Weck, 2018). However, in the various studies, it was possible to identify the strategies that the parents used to try to solve the dilemma.

\footnotetext{
1 In the same research project, James et al. (2010) published additional in-depth results on middle-class parents who behaved counterintuitively and solved the dilemma by leaning toward being "good citizens."
} 
The focus of previous studies has mostly been on parents who live in mixed neighborhoods with local schools that have a relatively large proportion of socially disadvantaged students or children with a migrant background. However, parents did not choose these schools by accident. When choosing a school and after enrolling their children in these schools, middleclass parents tended to use the following strategies:

1) Compensation Strategy: Parents mentioned that education and knowledge not provided in school can be compensated for at home. This strategy is closely related to the economic, social and cultural capital of middle-class families (Raveaud \& van Zanten 2007; Crozier et al. 2008; Cucchiara, 2013). James et al. (2010) pointed out that this strategy is often connected to the idea that children learn numerous intercultural competences at a mixed school and that this is important in "a globalized, socially diverse, multicultural world" (p. 625).

2) Monitoring Strategy: Parents monitor the teachers, as well as the children's development at school. They are highly engaged with the school and try to influence the teachers and principals (Crozier et al., 2008).

3) Critical Mass Strategy: Middle-class parents try to get their child tracked with other middle-class children, for example, in music classes, by justifying this intra-school segregation on the basis of cultural preferences (Raveaud \& van Zanten, 2007). What seems to be relevant for these parents is the idea of "critical mass": It is necessary for there to be other children at the school who are "like us" (Crozier et al., 2008; Kimelberg \& Billingham, 2012; Cucchiara, 2013). Corresponding to this, some principals try to attract enough middle-class children through multiple initiatives and thus try to improve the schools' results, climate, and reputation (also called Bridging Strategy, Raveaud \& van Zanten, 2007).

The focus of the previous studies was on parents who, in their heterogeneous neighborhoods, chose the local mixed school where middle-class families were underrepresented. Although tracking and bridging strategies can lead them to select specific classes or tracks in which children from middle-class families are more likely to be found, all these schools can still be described as mixed. Another option that has received less attention so far is opting for a private school, which is accessible to middle-class parents in various neighborhoods as well. In this paper, we therefore not only aimed to provide a German perspective on the issue of school choice dilemmas, but we also wanted to discuss the strategy of choosing a private school to solve the dilemma. The paper focused on the following questions: 
- How do parents describe the dilemma of being "good parents" or "good citizens" when choosing a primary school?

- Which strategies do parents in Berlin, Germany, apply to solve the dilemma?

- What role do private schools play in the dilemma?

\section{School Choice in Germany}

To aid comprehension of the results, the most important aspects of the German education system with regard to school choice are briefly presented. Above all, it is important to mention that the German school system is organized at the individual state level: There is no single German school system, but each of the sixteen federal states specifies how the schools and the education system work in that state. For example, most federal states have a four-grade primary school. However, in Berlin, where the data were collected for this study, as in Brandenburg, the transition to secondary school takes place after the sixth grade. Other differences exist, for example, in the curriculum, transition requirements and organization, the financing of public and private education, and teacher training. Nevertheless, some aspects of the school system apply throughout Germany. For example, all federal states have mandatory catchment areas for primary schools. The catchment areas are linked to the family's place of residence and have the aim of both minimizing the distance to primary school and avoiding spatial segregation (Schwarz et al., 2017). Nevertheless, federal state laws provide opportunities to choose a school other than the assigned one, based on whether there is a sibling, the school profile or whether it is an all-day school (Mayer \& Koinzer, 2019). In 2019 about 45 per cent of all Berlin parents of primary school starters applied for a school outside the catchment area (Abgeordnetenhaus Berlin, 2019). In the context of educational governance, this also applies to the increasingly differentiated school landscape in urban areas and the demand for more freedom of choice voiced by many families.

In this respect, there has been a great increase in private schools over the last ten years (Statistisches Bundesamt, 2018). Nevertheless, at 9.1\%, Germany still has a relatively small proportion of students in private schools by international standards (ibid; Koinzer et al., 2017). Private schools give parents the opportunity to choose a school outside the mandatory catchment area and are available in all German federal states - although not to the same extent (Statistisches Bundesamt, 2018). Unlike in many other countries, private schools in Germany are heavily subsidized by the state (socalled "government-dependent private schools"), which means that school fees are usually lower than in countries with independent private schools 
(Dronkers, 2008). Nevertheless, school fees in Germany vary from less than $€ 100$ to more than $€ 800$ per month, depending on the school and often based on the parents' income ${ }^{2}$. With school profiles that attract middle-class families and tuition fees, private schools are regarded as additional factors that contribute to school segregation and enable parents to make a distinctive school choice (Mayer, 2019). Moreover, private schools can decide to admit students on the basis of an internal application procedure. It is assumed that they often try to attract a clientele that enables them to co-finance the school costs through fees. Additionally, schools compete for "suitable" and the "right" children or even high-performing students from resource-rich families (Gewirtz et al., 1995). This can lead to either a good fit or a mismatch between the family milieu on the one hand and the school on the other (Kramer \& Helsper, 2010), and this can lead to different preferences with regard to individual school choices.

\section{Sampling}

To answer these research questions, we used data collected in the $\mathrm{CHOICE}^{3}$ research project, which explored school choice in Berlin, Germany. Berlin is an attractive research field because it has a wide range of private and public (primary) schools. Moreover, similar to other (European) cities, former working-class districts and inner-city neighborhoods have changed dramatically in recent years (Olszweski \& Sadovi, 2003). These changes can also be seen in urban school choice behavior, and choosing the "right" school depends on the neighborhood and the educational structure within the neighborhood. Following the studies described above, we looked at mixed, fairly marginalized, ethnically mixed inner-city neighborhoods with (small) gentrified areas that attracted middle-class families. Official statistics on Berlin's social environment (SenGesSoz, 2014) were used to identify such neighborhoods using indicators such as child poverty rate or status index $^{5}$.

2 Specific data and average prices are not available for Germany. The range given here is based on our field research in Berlin and the results of an analysis of the legal requirements regarding school fees by Wrase et al. (2017).

3 CHOICE is a DFG-funded project (project number 258445726) that was conducted under the direction of Prof. Thomas Koinzer (Humboldt-Universität zu Berlin) and Prof. Sabine Gruehn (University of Muenster) from 2014 to 2017.

4 Child poverty is defined by the proportion of children aged under 15 whose families depend on social or unemployment benefits (SenStadtUm 2015: 11).

5 The status index describes the social situation or status of a neighborhood. The calculation is carried out via a staged index procedure, including unemployment, long-term unemployment, transfer payments, and child poverty as indicators. The status index is divided into four classes, and neighborhoods are assigned to these according to their status index value. (SenStadtUm 2015: 49). 
Moreover, we decided to focus on school choice in the German primary school sector. Choosing a primary school is linked to a higher level of parental effort because the obligatory catchment areas mean that children are allocated to a particular school. Therefore, changing this pre-selection requires not only cultural capital such as knowledge of the educational system but also temporal and often economic and social resources - in other words, aspects associated with middle-class parents. Consequently, educational decisions are not made lightly and can be verbalized in interviews. Another reason for deciding to analyze choice of primary school rather than secondary school is that only parental preferences and school capacity need to be considered. Choosing a secondary school also involves decisions about different tracks, and the student's school performance and teacher recommendations are also decisive in student admission.

As already indicated, a substantial part of the school-choice research concentrates on decisions made by parents belonging to the middle class. Nevertheless, the middle class does not exist. In reality the middle class is made up of different subcultures and milieus which have in common the characteristic that they are neither very poor nor very rich. In addition, they are very well-educated and most have completed secondary school and often a university degree (Mau, 2014; Nast \& Blokland, 2014).

In order to answer the research questions, we rely on 24 semi-structured interviews that were conducted as part of the CHOICE in 2015 right after the school year began. The parents were asked why they had chosen that particular primary school for their child. The interviews focused on social distinctions within the school choices as well as habitually conducted decision-making. Moreover, issues such as socio-spatial reasons behind school choices or aspects of the neighborhood were covered in the interviews. Additionally, strategies referring to school choice could be identified from the data. In the interviews, however, no direct questions were asked about dilemmas regarding choice of school. The conversations lasted an average of 64 minutes and were recorded on a dictation machine and transcribed afterward.

After examining the neighborhood composition, four appropriate quarters could be identified in the sample. A total of eight interviews had been conducted with residents of these four urban, mixed quarters. The subsample was randomly distributed and two parent interviews were conducted in each neighborhood. All interviewees could be described as middle-class parents 
with close links to education ${ }^{6}$, who nevertheless differed in both income ${ }^{7}$ and professional status ${ }^{8}$. In two of the eight cases the parents had opted for a private school, while the other six interviews were conducted with parents who had chosen a public school. Table 1 presents details about the neighborhoods, the parents interviewed, and the schools they chose.

Table 1 Description of the interview sample

\begin{tabular}{|c|c|c|c|}
\hline & Neighborhood ${ }^{9}$ & Family Background ${ }^{10}$ & School $^{11}$ \\
\hline 1 & \multirow[b]{2}{*}{$\begin{array}{l}\text { Child Poverty } \\
\text { around } 20 \% \text { (Low/ } \\
\text { Middle), Status } \\
\text { Index } 2 \text { (Middle) }\end{array}$} & $\begin{array}{l}\text { Both parents have a university } \\
\text { degree and monthly household } \\
\text { income is high }{ }^{12} \text {. The family has } \\
\text { been living in the neighborhood } \\
\text { for } 10 \text { years. }\end{array}$ & $\begin{array}{l}\text { Son attends Pine Tree School, } \\
\text { a public school with no special } \\
\text { profile. In recent years, many } \\
\text { apartments have been built } \\
\text { that are popular with young } \\
\text { families, and the older housing } \\
\text { stock in the neighborhood has } \\
\text { been modernized. } \\
\text { Proportion of students with } \\
\text { a non-German language of } \\
\text { origin: } 20.2 \%\end{array}$ \\
\hline 2 & & $\begin{array}{l}\text { Both parents have a university } \\
\text { degree and work full-time } \\
\text { as freelancers. The monthly } \\
\text { household income is high. The } \\
\text { family has been living in the } \\
\text { neighborhood for } 6 \text { years. }\end{array}$ & $\begin{array}{l}\text { Son attends a public school, } \\
\text { Sunflower School, which has } \\
\text { two different tracks. One is } \\
\text { a regular primary school track } \\
\text { with no special profile. The } \\
\text { second has a bilingual profile } \\
\text { (German-Spanish). The school } \\
\text { inspection report points to } \\
\text { major problems, especially with } \\
\text { regard to the regular school } \\
\text { track. } \\
\text { Proportion of students with } \\
\text { a non-German language of } \\
\text { origin: } 65.4 \%\end{array}$ \\
\hline
\end{tabular}

6 All parents had a university degree, with the exception of one mother who was still studying.

7 The household net equivalized income used for this purpose was calculated using the OECD-modified scale (Eurostat 2018). The first adult receives a value of 1, and then every other person aged over 14 living in the household receives a value of 0.5 . Children under the age of 14 are weighted with the value 0.3 (ibid). A family with a mother, a father, two children aged 7 and 3 , and a household income of $€ 5,000$ would therefore have a household net equivalent income of: $€ 5,000 /(1+0.5+0.3+0.3)=€ 5,000 / 2.1 \approx € 2,381$.

8 Allocation was based on the Erikson-Goldthorpe-Portocarero-Index (EGP), aggregated at the household level.

9 Data source: SenGesSoz (2014). The data were rounded to conceal the exact neighborhood.

10 Data source: Interviews and survey data, $\mathrm{CHOICE}$ project

11 Data source: SenBildWiss (n.d.)

12 To ensure anonymity, family household income was classified into three categories: "low," "average," and "high." The categories were based on the Berlin average $(€ 1,402$ - Amt für Statistik Berlin-Brandenburg. (2016). Regionaler Sozialbericht Berlin und Brandenburg 2015. Potsdam: Amt für Statistik Berlin-Brandenburg). 


\begin{tabular}{|c|c|c|c|}
\hline 3 & \multirow[t]{2}{*}{$\begin{array}{l}\text { Child Poverty } \\
\text { around } 25 \% \\
\text { (Middle), Status } \\
\text { Index } 2 \text { (Middle) }\end{array}$} & $\begin{array}{l}\text { Both parents have a university } \\
\text { degree and an average monthly } \\
\text { income. The family has been } \\
\text { living in the neighborhood for } \\
12 \text { years. }\end{array}$ & $\begin{array}{l}\text { Son attends a public school, } \\
\text { Blueberry School, which has } \\
\text { two different tracks for the } \\
\text { afternoon program: an all-day } \\
\text { school track organized by the } \\
\text { school and a more alternative } \\
\text { after-school activity organized } \\
\text { by a parental initiative. } \\
\text { Proportion of students with } \\
\text { a non-German language of } \\
\text { origin: } 40.5 \%\end{array}$ \\
\hline 4 & & $\begin{array}{l}\text { Single mother, currently } \\
\text { studying and working part- } \\
\text { time as a writer. She has a low } \\
\text { monthly household income. The } \\
\text { family has been living in the } \\
\text { neighborhood for } 9 \text { years. }\end{array}$ & $\begin{array}{l}\text { Son attends Blueberry School } \\
\text { (described above). }\end{array}$ \\
\hline 5 & \multirow[t]{2}{*}{$\begin{array}{l}\text { Child Poverty } \\
\text { around } 40 \% \\
\text { (Middle/High), } \\
\text { Status Index } 2 \\
\text { (Middle) }\end{array}$} & $\begin{array}{l}\text { Both parents have a university } \\
\text { degree and the household } \\
\text { income is high. The family has } \\
\text { been living in the neighborhood } \\
\text { for } 7 \text { years. }\end{array}$ & $\begin{array}{l}\text { Daughter attends Hazelnut } \\
\text { School, a public school that } \\
\text { organizes the first three grades } \\
\text { with year-overlapping groups. } \\
\text { The school is in high demand } \\
\text { and performs well in the school } \\
\text { inspection. } \\
\text { Proportion of students with } \\
\text { a non-German language of } \\
\text { origin: } 55.5 \%\end{array}$ \\
\hline 6 & & $\begin{array}{l}\text { Both parents have a university } \\
\text { degree and household income is } \\
\text { high. The family has been living } \\
\text { in the neighborhood for } 8 \text { years. }\end{array}$ & $\begin{array}{l}\text { Son attends Hazelnut School } \\
\text { (described above). }\end{array}$ \\
\hline 7 & \multirow{2}{*}{$\begin{array}{l}\text { Child Poverty } \\
\text { around } 60 \% \\
\text { (High), Status } \\
\text { Index } 3.5 \text { (Low) }\end{array}$} & $\begin{array}{l}\text { Both parents have a university } \\
\text { degree and household income is } \\
\text { low. The father works full-time } \\
\text { as a restaurateur, the mother } \\
\text { works part-time as a writer. } \\
\text { The family moved into the } \\
\text { neighborhood shortly before } \\
\text { they enrolled their daughter in } \\
\text { school. }\end{array}$ & $\begin{array}{l}\text { Daughter attends Old Oak } \\
\text { School, a private Waldorf } \\
\text { School with an alternative, } \\
\text { anthroposophic model based on } \\
\text { the Rudolf Steiner approach. } \\
\text { School fees are approximately } \\
€ 175 / \text { month per child. } \\
\text { Proportion of students with } \\
\text { a non-German language of } \\
\text { origin: No data }\end{array}$ \\
\hline 8 & & $\begin{array}{l}\text { The mother is currently } \\
\text { studying and works part-time. } \\
\text { The father has a university } \\
\text { degree and works full-time. } \\
\text { Household income is average. } \\
\text { The family has been living in } \\
\text { the neighborhood for } 4 \text { years. }\end{array}$ & $\begin{array}{l}\text { Daughter attends a private } \\
\text { school, Elderflower School, } \\
\text { a protestant school. In addition } \\
\text { to the religious profile, which } \\
\text { includes regular church ser- } \\
\text { vices and religious lessons, the } \\
\text { school follows open teaching } \\
\text { concepts from various pedagog- } \\
\text { ical-reform approaches. } \\
\text { Proportion of students with } \\
\text { a non-German language of } \\
\text { origin: No data }\end{array}$ \\
\hline
\end{tabular}




\section{Methods}

We analyzed the eight interviews using qualitative content analysis (Mayring, 2014). In the first deductive step, a Theme Analysis was developed to establish whether the dilemma of being a good parent versus a good citizen was mentioned by the eight parents who were interviewed. All the passages in the transcript in which parents directly or indirectly mentioned the dilemma of school choice were coded for this purpose. We linked our findings to the research and other studies described above. In the second step, the parents' strategies for solving this dilemma were examined in more detail. The three strategies that we had already derived from the literature were divided into deductive categories. In addition, the resulting category system was supplemented by additional strategies, coded inductively from the material. This was necessary because, in our study, we examined the decision to send the child to a local school and the possibility that the parents from the heterogeneous neighborhoods would opt for a choice that would result in segregation, for example, by choosing a private school or a public school outside their neighborhood.

In order to improve the quality of the data and to avoid subjective biases, two people independently coded all the interviews. Any discrepancies were discussed at a coding meeting, and the categories and the classifications were adjusted accordingly.

\section{Findings}

The findings cannot be presented in detail for each case and interpretation step. Therefore, we refer only to the most characteristic parental statements to provide examples of each case. All the quotations were translated from German to English. Names, neighborhoods, and schools were anonymized to protect the participants.

\section{Dilemma in school choice}

All the parents in our sample mentioned the dilemma of choosing the "right" and a "good" school for their child ("good parent") and their integration into the neighborhood ("good citizen"). Nevertheless, there were differences in the ways parents presented the dilemma. Some of the parents tried to avoid schools with a large proportion of students with a migrant background and/or low social status. But after school started these parents were dissatisfied with the homogeneous middle class composition of the students 
For example, a father cheated by using a fake address to send his son to Blueberry School, a public school with an attractive afternoon program (for middle-class parents):

On the other hand, we cheated to get into this school. In this track. And we pay extra money for the care. We only want the best for our kids. [...] But this class doesn't reflect the social mix of the neighborhood. The classes could be more mixed. $(\# 3)^{13}$

Even though he later clearly stated that he had chosen this school because of the high proportion of children from privileged backgrounds, he otherwise thought the fact that only a very small proportion of children had a migrant background meant the school should be rated negatively. This can be interpreted as the dilemma between being a "good citizen" and integrating children from different social and ethnic backgrounds on the one hand and being a "good parent" placing the child in a "good" milieu and environment on the other. A mother who chose a private school, Elderflower School, for her daughter described it even more clearly:

I think it's okay that there is a tuition fee, but I know that not everyone can pay it and I know that that's why many people are excluded, [...] which means that I am quite aware that parents are being screened out because of finances or because of religion. [...] there is already a very one-sided picture of what the children experience in school, and yes, it is difficult. (\#8)

She put this statement into perspective and presented it in relation to the neighborhood and lower social milieus:

But, on the other hand, as a complacent mother, I am quite happy that I don't have to deal with these people every day. (\#8)

In addition, she made it clear that apart from the private school, she would only have considered public schools in a more privileged neighborhood because she "did not have a good feeling" (\#8) about the local schools in her neighborhood. She argued that she would like to enable her child to have the best experience that is possible in school.

13 The numbers after the \# refer to the interview. For an overview of the sample, see the table 1 . 
Most of the parents in our sample identified the dilemma in a similar way, directly in relation to the decision they made when choosing a school. However, in three of the interviews, the dilemma was not described so clearly in relation to the actual choice of school. Nevertheless, these parents mentioned that in another neighborhood or with another school within the catchment area, they would have been faced with the dilemma:

Actually, I was reassured that our street is still in the catchment area of this school. So maybe if I lived on the other side of the street where my kids would have to attend another school, I would have worried again. (\#6)

In this case, the dilemma seemed to be strongly related to the perceived social composition of the neighborhood and the "right" school catchment area, which will be discussed in more detail later.

When it came to the dilemma, most of the parents interviewed decided to be a "good parent." While the other studies did not specifically differentiate between these and often associated choosing the local school with being a "good citizen," our data showed that parents who chose the local school justified their decision by stating that they were trying to be good parents. Parents tried to implement "good parenthood" by employing various strategies - whether at a public local school or a private school. Only one mother in our sample decided to try to be a "good citizen." She repeatedly emphasized that for her it was "very important that [her son] was with girls and boys of different religions, skin colors, and social classes“ (\#2) partly because her son had a very privileged starting position compared with many other children in the neighborhood owing to the family resources and status. Furthermore, she pointed out that the school was a "disadvantage" (\#2) for her son, but in this context, she considered "social cohesion" to be „somehow more important.“

\section{Strategies}

All of the parents applied different strategies in deciding to be good parents or good citizens or at least to reduce the dilemma. The three strategies presented in the other studies could be found in our sample as well. In addition, we identified another two parental strategies.

The compensation strategy, already identified by various researchers (Raveaud \& van Zanten, 2007; Crozier et al., 2008; Cucchiara, 2013; James 
et al., 2010), refers to the family's resources. Parents try to supplement at home the knowledge and skills that might not be taught or might not be taught sufficiently in the local school. The mother who resolved the dilemma by seeking to be a "good citizen" justified her decision to send her child to the local (public) school based on the benefits of having a mix of students in comparison with private schools:

Indeed, we were a bit worried about choosing this school because it doesn't have the best reputation. [...] It was a conscious choice to put him in this public school instead of a private one. In private schools, people always stick with their own social class, and we wanted to prevent this from happening. (\#2)

When asked about solutions concerning her doubts about the quality of the school, she replied:

We thought the social cohesion and the social competences were somehow more important than whether he can add up or write. If it is necessary, he will experience and learn all that at home. (\#2)

Cucchiara (2013) also described the parents' worries that remained when they chose the local school and that were expressed by the mother in this interview. The strategy of compensating for the potential disadvantages in order to resolve the dilemma and the parents' doubts over the choice of school are linked to the resources a middle-class household can offer. Examples of this are private tuition, informal learning, or a subsequent change of school. Further, social learning in mixed classes is also seen by parents as an important future competence in an increasingly "globalized, socially diverse, multicultural world" (James et al., 2010, p. 625). The compensation strategy was also mentioned sometimes in other interviews. With this strategy, parents have control over homework or study and practice at home to ensure their children's learning success.

Closely linked to the strategy of compensation is the monitoring strategy, which Crozier et al. (2008) elaborated on in their study. Whereas with the compensation strategy, control is primarily carried out at the level of the child's learning success, with the monitoring strategy parents tend to "monitor" or attempt to influence the teachers. Parents who use this strategy are characterized by a high level of school commitment. The interviews with the Berlin parents showed that this is primarily implemented through parental classroom roles such as parent representatives: 
And then I figured, okay, parent representative. Come on, you can do this! Then you also have a bit more contact with them. I thought it would be a way to be better connected to the teacher. (\#4)

This sometimes close and frequent contact with the teachers and educators at the school was perceived as normal by these parents. However, this form of parental commitment seemed to be viewed critically by teachers and pedagogical staff, especially at local schools in mixed neighborhoods:

So the last time I talked to the teacher, I wanted to address a problem, and she was already very annoyed and said, "What are you complaining about now?" (\#2)

This indicates that parents apply the monitoring strategy but cannot do so successfully in all cases. Some interviews showed that parents experienced rejection from the pedagogical staff when they tried to use this strategy. However, studies of teacher recommendations during the transition to secondary school and grading (e.g. Neugebauer, 2010) have indicated that teachers still treat students in a privileged manner when they know the students come from committed and educated family backgrounds. Therefore, this strategy may also be effective despite being rejected by the school's pedagogical staff.

Raveaud and van Zanten (2007) pointed out a third strategy used by middle-class parents in mixed neighborhoods is to place children "in classes with other middle class children" (p. 121). Crozier et al. (2008, p. 264) and Kimelberg and Billingham (2012, p. 220) described this as "critical mass strategy." This strategy could also be found in the data set of the Berlin parents. For instance, one father solved the dilemma by choosing the local school, Blueberry School, and the track offering special afternoon care that attracted other middle-class parents as well. As already mentioned in the interview section above, this father put a lot of effort into getting his son enrolled at this school. For this purpose, he gave a false address when he registered his son for school so he was in the right catchment area for the school. A mother whose son also attended this special school-track stated that the classes were called "Bullerby ${ }^{14}$ classes" in reference to the children's book written by Astrid Lindgren - or even worse "Arian classes" (\#4). On the one hand, both parents were looking for exactly the kind of school environment that would meet their own academic expectations. If the pro-

14 "Noisy Village" in the US. 
portion of migrants in the class was too high, these parents saw the danger that "everybody is held up because nobody speaks German" (\#4). On the other hand, both families took a critical view of this middle-class composition of their "Arian classes." This was contextualized not only in the very heterogeneous and migration-influenced neighborhood but also due to the separation of students according to their social background within the two different school tracks.

I thought it was a "normal" mixture. However, our class now consists completely of children from educated backgrounds... only lawyers, doctors, artists, filmmakers. That's a little too much. (\#4)

In contrast to the results of the studies summarized above, the parents interviewed were very critical, at least retrospectively, of their having used the tracking strategy to solve the dilemma. This showed that the dilemma remained in some form even after the school had been chosen. Although the parents only chose the local school when there was a sufficient number of other middle-class children in the class, a too large proportion of children from privileged backgrounds was also criticized. A kind of "bad conscience" could be inferred, and this also affected the parents after choosing a local school with a segregated track.

The study by Raveaud and van Zanten (2007) pointed to a bridging strategy that is closely connected to the critical mass strategy. This sub-strategy was mentioned in our data as well. While talking about her impressions of an informational meeting, a mother pointed out the role of the principal and the top-down strategy of the school in attracting middle-class parents:

The point was that the principal showed off what a great school he was in charge of and that everybody wants to attend his school. [...] And then he emphasized that there are a lot of opportunities for topperforming students such as learning French in the second grade. (\#4)

The principal's strategy seemed to be successful in highlighting the merits of his school for middle-class parents, which was also reflected in the parents' statements about the critical mass strategy for Blueberry School. Using buzzwords such as "top-performing" and the early start in learning a foreign language tended to appeal to highly educated and educationally interested parents. 
Our data also showed that the two private schools in this study actively sought the "right“ clientele. Old Oak School, a private Waldorf school based on Rudolf Steiner's pedagogy, illustrated this in an exemplary way. The school had several mandatory informational meetings where different buzzwords were used to improve the fit between the parents and the school:

Of course, they always want the right pedagogical background. Such a kind of attitude. Someone who has nothing to do with this kind of education - they don't want that so much. They want people where they know they're on this line. (\#7).

The school very clearly communicated that the students were from families of the same background and with the same "attitude." On the one hand, it could be assumed that a private school with a Waldorf profile was not wellknown to parents from lower social backgrounds or was dismissed as too extravagant. On the other hand, with this form of communication, it could be assumed that parents attending the informational sessions and who did not have the "right" habitus or parenting style were discouraged from applying to the school and ultimately rejected. This led to a two-way fit between the school and the parents but also to homogenization toward the middle class.

In addition to the strategies outlined above, the parents identified two other ways to solve the dilemma in our interviews. In three interviews, a strategy that could be described as "downward comparison" became clear. As already indicated in the results on the identification of the dilemma, parents only indirectly indicated the decision was between being a good parent and a good citizen, and the dilemma was not so clear in relation to parents' choice of school. Nevertheless, these parents mentioned that in another neighborhood or with another school within the catchment area, they would have been faced with that dilemma. All three interviewees sent their children to the local school within the catchment area. In doing so, they were not faced with the dilemma as in their case both the neighborhood and the school were perceived as "very pleasant" (\#6) in comparison with other areas and schools. According to the official statistics on the student composition in the respective schools (SenBildWiss n.d.), the proportion of students from disadvantaged family backgrounds was quite high. For example, 55.5\% of the children at Hazelnut School did not speak German as their first language, and about a third of the children came from families on social welfare benefits. Nevertheless, the parents described it as a good school with a good social and ethnic mix, especially in contrast to other schools in neighborhoods with an even larger proportion of migrants. 
I know another school [in another neighborhood] that is not very popular. [...] There's an extremely high percentage of migrants. (\#5)

Looking at the statistics for this school, the proportion of students who did not speak German as their first language was around 10\% higher than at the school the parents chose. However, other schools that were also located at a comparable distance and had a substantially smaller proportion of children with a migration background were not used as a comparison. To describe this behavior and such justifications, social psychology uses the theory of social comparison (Festinger, 1954). It is assumed that a person's own decisions depend on different comparative figures. The downward comparison can help the person achieve greater satisfaction with the decision or - in this case - the person can resolve the dilemma.

Finally, the strategy of choosing a private school to resolve the dilemma was also evident in our data. Choosing a private school was directly related to an explicit decision to be a "good parent." Despite being aware of the inequality and segregation associated with the choice of school, they considered the benefits for their own children to be more important. As already mentioned in the interview quoted above, the mother explicitly addressed the fact that low-income families and Muslim families were segregated at Elderflower School, her school of choice. She viewed this critically, but she was also glad that she did not have to deal with people from other milieus (\#8). The strategy of solving the dilemma by choosing a private school was particularly evident in the two interviews with middle-class parents who lived in highly marginalized neighborhoods. Almost two out of three children in this neighborhood lived in families who were on welfare. These parents chose a private school and thus avoided the local schools with a student clientele that did not correspond with their conception. While most studies of school choice in mixed neighborhoods have so far focused only on parents who chose public schools, it is short-sighted to exclude parents who chose other options such as private schools.

Looking at all of the interviews, it became clear that the composition of the neighborhood seemed to play an important role. A socially and ethnically mixed neighborhood and school not only seemed to be tolerated, but in many cases also appeared to be desired by the middle-class families. However, there were indications in our interviews that a certain limit must not be crossed. The parents interviewed mainly based their decisions on the proportion of students with a migrant background. Once a certain threshold was reached, the local school was no longer seen as a potential option, 
for example, by the parents who opted for a private school. This was also evident in the interviews where parents applied the critical mass strategy, although in a different form. On the one hand, they criticized the school for having a large proportion of German middle-class children. On the other hand, a school with „80\% children who simply do not speak German at home“ (\#4) was not an option. The parents preferred a "fifty-fifty" (\#4) mixture. This perceived threshold became clear in relation to the strategy of downward comparison as well. When everything was still fine in the person's neighborhood, the proportion of children with a migration background in neighboring areas was regarded as too high. It seemed that the dilemma primarily depended on the proportions in the social mix or more specifically on the perceived migration backgrounds of potential classmates.

\section{Summary and Conclusion}

All strategies mentioned by other researchers could be found in Berlin as well. In addition, there were two more strategies applied by middle-class parents who chose a school for their child in heterogeneous neighborhoods. First, parents used the strategy of downward comparison to relate their choice of the local school to other neighborhoods that were classified as "even worse" in terms of migrant background and social situation. Second, two parents living in strongly marginalized neighborhoods chose a private school as an exit option and therefore avoided the local school landscape that had many students from migrant or disadvantaged families.

It was noticeable that the perceived proportion of children with migrant backgrounds played a major role in relation to the dilemma and the strategies that were chosen. Future studies should explore how these boundaries differ, whether there are differences in thresholds, and whether parental assessments are related to the actual statistics and composition of schools and neighborhoods. In particular, the reasons parents take a critical view of a high proportion of children with a migrant background should be investigated. Schelling's model of segregation (1969) can provide some good connection points. This model can be used to show that even when parents do not lean toward segregation ("good citizens"), minor decisions such as the choice of a school at the micro-level can have substantial social consequences and increase segregation at the macro level.

While our sample investigates a very specific kind of parent in a certain urban environment, our findings underline the idea that there is a strong link between spatial segregation and segregation based on school choice. 
Only one family solved the dilemma of being "good parents" or "good citizens" by opting for a more integrated school system. Most families who were confronted with choosing a primary school in a heterogeneous neighborhood opted for a strategy that could ultimately be attributed to being "good parents." On the one hand, parents applied strategies that did not encourage them to choose the local school and favored a "good parenting" decision. For example, attempts were made to place the children in schools with many other middle-class families "like us" (critical mass/bridging strategy). In addition, strategies were used to monitor school success or to support it outside of school (monitoring and compensation strategy). On the other hand, parents avoided local schools by choosing private schools.

However, the increasing levels of segregation should not be blamed on the parents (alone). In a society in which the child's education is perceived to be the most important factor (Reckwitz, 2017), and choices are promoted, the educational system as such must be considered as well. The parents themselves are not the source of the dilemmas they face. As Oria et al. (2007) showed, in an education system in which equality does not exist, it is education policy above all else that is responsible. The increasing promotion of school choice policies such as in Germany and many other countries has tended to intensify parental dilemmas as well as educational inequalities and segregation. Instead of continuing to focus on economization and freedom of choice in the school system, quality and resources in all schools but especially those in disadvantaged neighborhoods - should be improved.

\section{Acknowledgements}

First of all we would like to thank all the parents who took part in our interviews. Further thanks go to Jane Zagorski and the reviewers for their helpful comments on the manuscript. Last but not least, many thanks to all the project members for their help.

\section{References}

Abgeordnetenhaus Berlin (2019). Antwort auf die Schriftliche Anfrage Nr. 18/21834 vom 3. Dezember 2019 über Schulplatzklagen in Berlin. Retrieved from http://pardok.parlament-berlin.de/starweb/adis/citat/VT/18/SchrAnfr/S18-21834.pdf

Amt für Statistik Berlin - Brandenburg (2016). Regionaler Sozialbericht Berlin und Brandenburg 2015. Potsdam: Amt für Statistik Berlin - Brandenburg.

Ball, S., \& Vincent, C. (2007). Distinction, representation and identities among middle class fractions in London. In T. Richard, S. Lamb, \& M. Duru-Bellat (Eds.): International Studies in Educational Inequality, Theory and Policy (p. 63-87). Springer. 
Bourdieu, P. (1983). Ökonomisches Kapital, kulturelles Kapital, soziales Kapital. In R. Kreckel (Ed.): Soziale Ungleichheiten (p. 183-198). Schwartz.

Butler, T., \& Robson, G. (2003). London calling: The middle class and the remaking of inner London. Berg.

Crozier, G., Reay, D., James, D., Jamieson, F., Beedell, P., Hollingworth, S., \& Williams, K. (2008). White middle-class parents, identities, educational choice and the urban comprehensive school: Dilemmas, ambivalence and moral ambiguity. British Journal of Sociology of Education, 29(3), 261-272.

Cucchiara, M. (2013). “Are we doing damage?" Choosing an urban public school in an era of parental anxiety. Anthropology \& Education Quarterly, 44(1), 75-93.

Dronkers, J. (2008). Differences in scholastic achievement of public, private government-dependent, and private independent schools. A cross-national analysis. Educational Policy, 22(4), 541-577.

Eurostat (2018). Glossary. Equivalised Disposable Income. https://ec.europa.eu/ eurostat/statistics-explained/index.php/Glossary:Equivalised_disposable_income Festinger, L. (1954). A theory of social comparison processes. Human Relations 7 , 117-140.

Förste, D. (2013). Cheating the lottery... Correlations between a state regulated school system, access to high quality schooling and middle class school choice in Berlin. RC21 Conference. http://www.rc21.org/conferences/berlin2013/RC21-Berlin-Papers /32-1-Foerste.pdf

Frank, S., \& Weck, S. (2018). Being good parents or being good citizens: Dilemmas and contradictions of urban families in middle-class enclaves and mixed neighbourhoods in Germany. International Journal of Urban and Regional Research 42(1), 2035.

Gewirtz, S., Ball, S. J., \& Bowe, R. (1995). Markets, choice, and equity in education. Open University Press.

James, D., Reay, D., Crozier, G., Beedell, P., Hollingworth, S., Jamieson, F., \& Williams, K. (2010). Neoliberal policy and the meaning of counterintuitive middle-class school choices. Current Sociology, 58(4), 623-641.

Kimelberg, S., \& Billingham, C.M. (2012). Attitudes toward diversity and the school choice process middle-class parents in a segregated urban public school district. Urban Education, 48(2), 198-231.

Koinzer, T., Nikolai, R., \& Waldow, F. (2017). Private schooling and school choice as global phenomena: An introduction. In T. Koinzer, R. Nikolai, \& F. Waldow (Eds.), Private schools and school choice in compulsory education (p. 1-6). Springer.

Kramer, R.-T., \& Helsper, W. (2010). Kulturelle Passung und Bildungsungleichheit - Potentiale einer an Bourdieu orientierten Analyse der Bildungsungleichheit. In H. H. Krüger, U. Rabe-Kleberg, R.-T. Kramer, \& J. Budde (Eds.), Bildungsungleichheit revisited. Bildung und soziale Ungleichheit vom Kindergarten bis zur Hochschule (p. 103-126). Springer.

Mau, S. (2014). Die Mittelschicht - das unbekannte Wesen? Aus Politik und Zeitgeschichte (APUZ) 49, 3-10.

Mayer, T., \& Koinzer, T. (2019). Schulwahl und Bildungsungleichheit - Ein holistisches Modell zur Erklärung von Segregation und Bildungsdisparitäten bei der Einzelschulwahl. Pädagogische Rundschau, 73(3), 265-279. 
Mayer, T. (2019). "Und dann geht natürlich nur der Weg zur Privatschule" - Individuelle Schulwahlprozesse und Einzelschulwahl an privaten Grundschulen. Zeitschrift für Erziehungswissenschaft, 22(2), 389-410.

Mayring, P. (2014). Qualitative content analysis: Theoretical foundation, basic procedures and software solution. Klagenfurt. https://nbn-resolving.org/urn:nbn:de:0168-ssoar-395173

Nast, J., \& Blokland, T. (2014). Social mix revisited: Neighbourhood institutions as setting for boundary work and social capital. Sociology, 48(3), 482-499.

Neugebauer, M. (2010). Bildungsungleichheit und Grundschulempfehlung beim Übergang auf das Gymnasium: Eine Dekomposition primärer und sekundärer Herkunftseffekte. Zeitschrift für Soziologie, 39(3), 202-214.

Olszweski, L., \& Sadovi, C. (2003). The rebirth of schools set for south side CHA and a-list of institutions have a big plan. The Chicago Tribune, 19.12.2003.

Oria. A., Cardini, A., Ball. S., Stamou, E., Kolokitha, M., Vertigan, S., \& Flores-Moreno, C. (2007). Urban education, the middle classes and their dilemmas of school choice. Journal of Education Policy, 22(1), 91-105.

Raveaud, M., \& van Zanten, A. (2007). Choosing the local school: middle class parents' values and social and ethnic mix in London and Paris. Journal of Education Policy, 22(1), 107-124.

Reckwitz, A. (2017). Die Gesellschaft der Singularitäten. Suhrkamp.

Schelling, T. (1969). Models of segregation. The American Economic Review, 59 (2). 488-493.

Schwarz, J., Habeck, C., Gruehn, S., \& Koinzer, T. (2017). School choice in German primary schools. In T. Koinzer, R. Nikolai, \& F. Waldow (Eds.), Private Schools and School Choice in Compulsory Education (p. 177-199). Springer.

SenBildWiss - Senatsverwaltung für Bildung, Jugend und Wissenschaft (n.d.). Schulverzeichnis. https://www.berlin.de/sen/bildung/schule/berliner-schulen/ schulverzeichnis/?

SenGesSoz - Senatsverwaltung für Gesundheit und Soziales (2014). Handlungsorientierter Sozialstrukturatlas Berlin 2013. Berlin.

SenStadtUm - Senatsverwaltung für Stadtentwicklung und Umwelt Berlin (2015). Monitoring Soziale Stadtentwicklung 2015. http://www.stadtentwicklung.berlin. de/planen/basisdaten_stadtentwicklung/monitoring/download/2015/MonitoringSozialeStadtentwicklung2015.pdf

Statistisches Bundesamt (2018). Bildung und Kultur. Private Schulen. Schuljahr 2017/2018. Fachserie 11, Reihe 1.1. https://www.destatis.de/DE/Themen/Gesellschaft-Umwelt/Bildung-Forschung-Kultur/Schulen/Publikationen/Downloads-Schulen/private-schulen-2110110187005.xlsx

Wrase, M., Jung, L., \& Helbig, M. (2017). Defizite der Regulierung und Aufsicht von privaten Ersatzschulen in Bezug auf das Sonderungsverbot nach Art.7 Abs 4 Satz 3 GG. WZB Discussion Paper P2017-003. https://bibliothek.wzb.eu/pdf/2017/p17003.pdf 


\section{Authors:}

Tanja Mayer

Humboldt-Universität zu Berlin

Kultur-, Sozial- und Bildungswissenschaftliche Fakultät

Institut für Erziehungswissenschaften

Unter den Linden 6

10099

Berlin

Germany

Email: tanja.mayer@hu-berlin.de

Viktor Geist

Humboldt-Universität zu Berlin

Kultur-, Sozial- und Bildungswissenschaftliche Fakultät

Institut für Erziehungswissenschaften

Unter den Linden 6

10099

Berlin

Germany

Email: viktor.geist.1@hu-berlin.de

Vera S. Pohl

Humboldt-Universität zu Berlin

Kultur-, Sozial- und Bildungswissenschaftliche Fakultät

Institut für Erziehungswissenschaften

Unter den Linden 6

10099

Berlin

Germany

Email: vera.sophie.pohl@hu-berlin.de

Judith Schwarz

Universität Münster

Institut für Erziehungswissenschaft

Arbeitsgruppe Schultheorie / Schulforschung

Bispinghof 5/6

48143

Münster

Germany

Email: judith.schwarz@uni-muenster.de

Thomas Koinzer

Humboldt-Universität zu Berlin

Kultur-, Sozial- und Bildungswissenschaftliche Fakultät

Institut für Erziehungswissenschaften

Unter den Linden 6

10099

Berlin

Germany

Email: thomas.koinzer@hu-berlin.de 